\title{
UNEMPLOYMENT INSURANCE: SUPPLEMENTAL UNEMPLOYMENT BENEFIT PLANS
}

$\mathrm{O}_{\text {RGanized labor's effort to increase the worker's fringe benefits was }}$ materially advanced in 1955 with the origination and initial acceptance by management of Supplemental Unemployment Benefit (SUB) Plans, ${ }^{1}$ which provide payments in addition to the state unemployment compensation. SUB plans, promoted by the dual fear of recurrent unemployment and inadequate state unemployment insurance, are designed to supplement rather than to duplicate benefits obtainable under state plans. ${ }^{2}$

The North Carolina Supreme Court in In Re Shuler ${ }^{3}$ recently overruled the previously established rule of the North Carolina Employment Security Commission and became the first court of last resort

'The first SUB plan was created in the contract negotiations between the United Automobile Workers Union and Ford Motor Co. For text of the original Ford plan see ${ }_{3} 6$ L.R.R.M. 64 (1955). SUB plans are principally found in the automobile, steel, aluminum, rubber, farm machinery and glass industries.

SUB plans fall into two basic groups-the pooled fund type in which the worker has no vested interests, exemplified by the Ford plan, and the individual account type exemplified by the glass industry plan. This latter plan is similar to a compulsory saving plan, as the worker has a vested interest in the employer's contribution to his individual account which may be used to finance either voluntary or involuntary unemployment and has no relationship to state unemployment insurance. See Wickersham, Controlling Unemployment at the Company Level, I4 IND. \& LAB. REL. REV. 68, 78 (1960); 47 L.R.R.M. 31 (1961). For a description of these two types of SUB plans see U.S. BUREAU OF EMPLOYMENT SECURITY, DEP'T OF LABOR, SUPPLEMENTAL. UNEMPLOYMent Benefit Plans and UNemployment Insurance 5-8 (1957); i A CCH UNemp. INS. REP. 12300 (196I).

This note is limited to an examination of the Ford type plan which is the most common SUB arrangement.

2 "It appears clear to us that the [SUB] plan by its very terms is in truth supplemental." Barco Mfg. Co. v. Wright, 1o Ill. 2d 157, 165, 139 N.E.2d 227,232 (1956). See also Conn. Atty. Gen. Op., 3 CCH UNEMP. INs. ReP. T 8380 (1955).

This supplementing purpose of the SUB plan distinguishes it from the Guaranteed Annual Wage (GAW) Plan which is a guarantee of employment or wages to a worker for a stated number of weeks during the contract year. See U.S. BUREAU OF EMPLOYMENT SEcURITY, op. cit. supra note 1, at 3-5; Comment, 29 RockY MT. L. REV. 232 (2957). The original SUB represented a workable compromise of the demands for a GAW plan. Chernick \& Naef, Legal and Political Aspects of the Integration of Unemployment Insurance and SUB Plans, 12 IND. \& LAB. REI. REV. 20, 33 (1958).

${ }_{255}$ N.C. 559,122 S.E.2d 393 (196I). For text of the rubber industry SUB plan involved in the Shuler case see Record on Appeal, pp. 12-45. 
to uphold the principle of supplementation. Two temporarily laid-off workers, having established their eligibility for state unemployment compensation, received supplemental payments from the SUB trust fund. Thereafter, the Commission treated these SUB payments as "wages" and reduced the state unemployment insurance benefits by the amount of the SUB payments. The claimants' protest of this deduction necessitated judicial determination of the issue of supplementation.

Although SUB plans are creatures of collective bargaining, their major characteristics have become standardized. To provide the ensuing supplemental payments, an independent trust fund is established and maintained at a predetermined maximum funding position by employer contributions. ${ }^{*}$ To be eligible for SUB payments the laid-off worker must be involuntarily unemployed and must meet the requirements for unemployment compensation in the state where he is employed. 5 Once eligible, the employee may receive a supplemental amount, not in excess of $\$ 25.00$ per week, which when added to his state unemployment benefits, will equal not more than 65 per cent of his normal after-tax straight time wage. ${ }^{6}$ Furthermore, SUB payments are contingent upon the state's "'recognition of the right of a person to receive both a state system unemployment benefit and a weekly supplement benefit under the plan for the same week of lay-off . . . without reduction of the state system unemployment benefit." "m Thus no SUB benefits are payable until a ruling is secured from the state

\footnotetext{
The employer must contribute a prescribed amount per employee hour to the fund in establishing and maintaining this maximum funding position. This advance funding and built-in limitation on the size of the fund and the fact that the amount and duration of SUB benefits are partially dependent on the trust fund position give the employer limited liability under the SUB plan. See Chernick \& Naef, supra note 2, at 33.

${ }^{5} \mathrm{~A}$ basic principle of the SUB plan is complete integration with the state unemployment compensation laws. To be eligible for SUB payments the worker must register and report to the proper state employment office, comply with the "seek work" and availability for suitable employment requirements of state law, serve a "waiting week" if such is required under applicable state law, and receive a state-system benefit not currently under protest by the company. But see 31 IND. L.J. 412, 417 n.32 (1956) (SUB benefits paid although laid-off worker ineligible for state unemployment benefits).

' In addition to this percentage limitation as to amount of supplemental benefits, the duration of SUB payments varies with the number of "credit units" the employee has acquired, his seniority, and the trust fund position at the time he is collecting SUB payments. Record on Appeal, pp. 24-25, In Re Shuler, 255 N.C. 559, 122 S.E.2d 393 (1961).

${ }^{7}$ In Re Shuler, 255 N.C. 559, 562, 122 S.E.2d 393, 395 (1961) (quoting from the SUB plan). This is the usual SUB plan definition of supplementation.
} 
that SUB payments do not prevent the laid-off worker from satisfying the statutory requirement of "total unemployment" for purposes of maximum state benefits. ${ }^{8}$

At present forty-six states have considered the question of supplementation. Forty-four states have allowed supplementation, ${ }^{9}$ while two states, Maine ${ }^{10}$ and Virginia, ${ }^{11}$ have prohibited it and thus have required the reduction of state unemployment benefits by the amount of SUB payments. However, only nine states have dealt with supplementation by legislative enactments; ${ }^{12}$ the remaining states having decided the question by administrative rulings. These rulings are not binding on the courts, as illustrated by the fact that the two decisions prior to Shuler to consider supplementation also overruled the position taken by the state agencies. ${ }^{13}$ Moreover, those two decisions were overturned

\footnotetext{
${ }^{8}$ In those states which do not permit snpplementation, alternate plans, providing periodic and lump sum payments designed to satisfy the state requirements, have been attempted with varying success. IA CCH UNEMP. INS. REP. I 2300 (1961).

- For a survey of the present state rulings and statutes on supplementation see IA CCH UNEMP. INS. REP. If 2300 (1961).

See generally U.S. BUREAU OF EMPLOYMENT SECURITY, op. cit. supra note $\mathbf{x}$, at 9-23 for an excellent examination of the status of supplementation as of September I957; INDUSTRIAL UNION DEP'T, AFL-CIO, SUPPLEMENTATION OF UNEMPLOYMENT BENEFITs (2d ed. 1957) for full text of rulings, statutes, and cases through October I 957 dealing with supplementation.

The majority position permitting supplementation was significantly strengthened in 1959, when the Indiana legislature reversed previous prohibitive enactments, and when statutory amendments in California and Ohio overruled unfavorable judicial decisions. See INd. ANn. STAT. $\S 52-1539$ (h) (Supp. 1961); OHIo ReV. Code ANN. § 4141.36 (Page Supp. 1961); CAL. Unemp. INs. § 1265 (West Supp. 196r).

New Hampshire, New Mexico, South Carolina and South Dakota have not passed on the validity of supplementation.

${ }^{10}$ Payments into and out of the SUB trust fund are considered "wages" under the Maine law. Me. Atty. Gen. Op., 5 CCH UNemp. INs. Rep. If 8142 (1960).

${ }^{11}$ Virginia is the only state whose law prohibits supplementation. The Virginia statute specifically includes "unemployment benefits under any private plan financed in whole or in part by an employer" within the meaning of the term "wage." VA. CODE ANN. § 60-22 (Supp. 1960).

${ }^{12}$ See Alaska Sess. Laws 1960 , ch. $60, \S 3 ;$ Cal. Unemp. INs. $\S$ I265 (West Supp. 1961); Colo. Rev. STAt. ANN. $\S 82-1-3(12)$ (g) (Supp. 1960); GA. CODE ANN. $§ 54-657(\mathrm{n})(2)$ (1961); HAWAII REv. LAWs $\S$ 93-11(i) (Supp. 1960); IND. ANN. STAT. $\$ 52-1539(\mathrm{~h})$ (Supp. 1961); Md. ANN. CODE art. 95A, § $20(\mathrm{n})(9)$ (1957); OHio Rev. COde ANn. § 4141.36 (Page Supp. 196r); VA. Code ANN. \& 60-22 (Supp. 1960).

${ }^{13}$ See Morris Furniture Mfg. Co. v. Employment Security Com'n, 2 CCH UNEMP. INs. REP. (Cal.) I 2300 (Super. Ct., Los Angeles County 1958); United Steelworkers v. Doyle, 168 Ohio St. 324, 154 N.E.2d 623 (1958).
} 
by subsequent legislation in their respective states, further indicating the unsettled status of supplementation. ${ }^{14}$

The decision in Shuler, as are most of the rulings on the question, is based on inherent policy considerations which offer strong support for the validity of supplementation. ${ }^{15}$ The SUB plan accomplishes a partial reallocation of the financial burden of unemployment from the unemployed worker to the entire work force covered by the plan, and thus affords the individual worker a sense of security against the risk of involuntary unemployment. ${ }^{18}$ Likewise, SUB encourages stabilization of employment by creating a cost of unemployment which is more directly felt by the employer than the cost reflected by the state's experience-rating systems used to determine an employer's compulsory contribution to the state unemployment compensation fund. ${ }^{17}$ The SUB plan, in implementing the declaration of policy of the state statute, enables higher unemployment compensation levels without increasing expenditures by the state, ${ }^{18}$ thus offsetting the inadequacies of the state unemployment insurance system. ${ }^{19}$ Furthermore, supplementation

\footnotetext{
${ }^{34}$ See CAL. UNEMP. INS. § 1265 (West Supp. 1961); OHIO REv. CODE $\$ 4141.36$ (Page Supp. 1961).

${ }^{38}$ The court focuses attention on the state employment security statute's declaration of public policy, N.C. GEN. STAT. $§ 96-2$ (1958), and then proceeds to show that supplemental benefits support this stated policy.

For an examination of the propositon that state SUB rulings are dependent on factors other than the statutory language see Chernick \& Naef, supra note 2. See also Masson \& Krislov, Supplemental Unemployment Benefits and Public Policy in Otio, 7 W. REs. L. REv. 436 (1956).

${ }^{10}$ See Chernick \& Naef, supra note 2, at 33; 31 IND. L.J. 412, 420-25 (1956) (discussion of economic consequences of supplementation).

${ }^{17} \mathrm{~A}$ basic objective of unemployment compensation legislation is to encourage stabilization of employment. To this end states have adopted experience-rating systems, so that the contributions of those employers having a high incidence of unemployment are greater than those who maintain employment at stable levels. See Comment, 53 MICH. L. REv. 849, 851-52 (1955). SUB plans have the same effect, since in the long run each employer's contribution to the SUB fund will depend directly on the amount of unemployment among his workers. It has been suggested that SUB, in encouraging reduction of unemployment, reduces the potential drain on state unemployment compensation funds. INDUSTRIAL UNION DEP'T AFL-CIO, op. cit. supra note 9, at 15 . See generally Wickersham, supra note 1.

But see Eberling, The Guaranteed Annual Wage and Unemployment Compensation, 8 VAND. L. REv. 458,473 (1955).

${ }^{28}$ Such increased unemployment benefits lighten the monetary impact of involuntary unemployment and enable the maintenance of a more substantial purchasing power. See Masson \& Krislov, supra note 15 , at 450 .

20 Some of the suggested deficiencies are the inadequacy of payments, the short duration of the benefit period, the extent of coverage, and the lack of provisions for
} 
necessitates a continuation of contact between the employer and laid-off employee, and this connection may return the employee to his job when it is available. ${ }^{20}$

On the other hand, arguments against the validity of supplementation have been advanced on the grounds of statutory invalidity and inconsistency with some of the basic purposes of state unemployment compensation. In support of these arguments, suggestions have been made that supplementation will reduce the unemployed worker's incentive to find new employment, ${ }^{21}$ that it will increase compulsory contribution to the state fund, ${ }^{22}$ and that the SUB plan lacks the uniformity characteristic of state unemployment compensation systems. ${ }^{23}$

In addition to weighing the various policy considerations, the validity of supplementation is also dependent on a favorable construction of the state's unemployment compensation statute. Although the Shuler decision failed to consider sufficiently this problem of construction, many rulings have been founded on an answer to the question: are SUB payments "wages" for "services" payable "with respect to" the week in which the state benefits are received, as defined by the unemployment statute, thus rendering the recipient not "totally unemployed," and

training the chronic unemployed. See Larson \& Murray, The Development of Unemployment Insurance in the United States, 8 VAND. L. REv. 181, 211-17 (1955); 3 IND. L.J. 412,419 n. 47 (1956).

${ }^{20}$ This was the only policy argument articulated in the Shuler decision. 255 N.C. at 562,122 S.E.2d at 395 .

${ }^{21}$ See Comment, 29 Rocky MT. L. REV. 232, 239 (1957). However, SUB benefits are generally within the non-deferrable expenditures standard frequently advocated as a proper level for state compensation. Moreover, worker's total benefits are still substantially less than his normal wages, and thus small enough not to interfere with the incentive to seek reemployment. See Wickersham, supra note I, at 80; 3 I IND. L.J. 412, 424 (1956).

22 This was the contention made in two suits brought by employers. In Illinois a petition to enjoin payment of state benefits to claimants receiving SUB benefits was denied on grounds that the supplemental payments had no effect on compulsory contributions to the state fund. Barco Mfg. Co. v. Wright, ro 1ll. 2d 157, 139 N.E.2d 227 (1956). In Connecticut a taxpayer's suit for declaratory judgment was denied because the taxpayer lacked standing. Manufacturers Ass'n v. Administrator, Unemp. Comp. Act, 26 Conn. Supp. xo8, 125 A.2d 317 (1956).

The dismissal of these efforts to contest rulings favorable to supplementation suggests that there will be few if auy future judicial tests of the question, since the proper parties, the employee, employer under the SUB plan, and the state, will not question its validity. For discussion of parties who might desire to contest the legality of suppleunentation see Masson \& Krislov, stupra note 15 , at 443-46.

${ }^{23}$ See generally Eberling, supra note 17 , at $469-70$; Comment, 29 RockY MT. L. REV. 232, 240-42 (1957). 
therefore ineligible for or subject to a deduction in state benefits? ${ }^{24}$ While the overwhelming majority of states have answered in the negative, the rationales are far from uniform.

The rulings which hold SUB payments not to constitute wages, and thus not deductible, rest on two basic premises. First, the employee does not have a vested right in the SUB fund, since eligibility depends primarily upon the meeting of conditions after layoff. Second, the SUB benefits received are in no way allocable to the worker's rendering of prior service, because the employer contributions into the fund are in no way dependent upon the employment of any particular employee. $^{25}$ The ruling of the Internal Revenue Service that SUB payments are not wages for purposes of Federal unemployment taxes or income tax withholding adheres to this argument. ${ }^{26}$

On the other hand, a few holdings, including the ruling of the North Carolina Commission ${ }^{27}$ prior to In Re Shuler and the other two judicial decisions on supplementation, ${ }^{28}$ have concluded that SUB payments do constitute deductible wages. These conclusions are based on the theory that supplemental benefits are paid as incident to the employer-employee relationship, and that the statutory term "wages" encompasses all economic benefits gained from this general employment

\footnotetext{
${ }^{24}$ For an excellent discussion of the possible construction of the words in quotations see Comment, Effect of Receiving Supplemental Unemployment Benefits on Eligibility for State Benefits, 69 HARV. L. REv. 362 (1955).

The typical state unemployment compensation statute provides that "an individual shall be deemed 'totally unemployed' in any week with respect to which no wages are payable to him and during which he performs no services." N.C. Gen. Stat. . § 96-8(11) (1958). "Wages" are normally defined as "[all] remuneration for personal services ..." Ill. ANN. Stat. ch. 48, \& $218(7)$ (g) (Smith-Hurd 1950).

${ }^{25}$ See, e.g., Ill. Atty. Gen. Op. No. 292, 4 CCH UNEMP. INS. REP. $\$ 2300$ (1956); N.Y. Atty. Gen. Op., N.Y. CCH UNEMP. INs. REP. If 8969 (1955). See Brief for the AFL-CIO as Amicus Curiae, pp. II-16, In re Shuler, 255 N.C. 559, 122 S.E.2d 393 (I96I).

In addition, the spurious suggestion is often made that the supplemental benefits are not "wages," because they do not come directly from the employer but are paid to the worker as beneficiary of the SUB trust fund. See, e.g., Mass. Atty. Gen. Op., 5 CCH Unemp. INs. REP. If 8188 (1955). Contra, United Steelworkers v. Doyle, I 68 Ohio St. $324,327,154$ N.E.2d 623, 625 (1958).

${ }^{20}$ Rev. Rul. 56-249, 1956-I CuM. BuLl. 488. For survey of federal rulings on supplementation see U.S. BUREAU of EMPLOYMENT SECURITY, op. cit. supra note I, at 24-25.

${ }^{27}$ For text of the previous North Carolina rulings see INDUSTRIAI UNION DEP'T, AFL-CIO, op. cit. supra note 9, at 143-45; Record on Appeal, pp. 92-111, In Re Shuler, 255 N.C. 559 , 122 S.E.2d 393 (1961).

${ }^{33}$ See cases cited note 13 supra.
} 
relationship. ${ }^{20}$ It is further argued that the laid-off worker continues his status as an available employee, retains seniority and pension rights, and must report to the employer weekly for SUB payments, and thus the supplemental benefits are remuneration for personal service. ${ }^{30}$

However, even if SUB payments are determined to constitute wages, it can be argued that they are not payable "with respect to" the week of unemployment but are compensation for services rendered in prior weeks of employment: thus the recipient is "totally unemployed" for purposes of the unemployment compensation statute, and the SUB payments need not be deducted. ${ }^{31}$ The North Carolina court, therefore, could have taken the more mechanistic statutory-construction approach and have soundly concluded that the supplemental benefits were not "wages with respect to" the period for which claimants were claiming state unemployment compensation. ${ }^{32}$

${ }^{20}$ This was the rationale of the judicial decisions prohibiting supplementation, Morris Furniture Mfg. Co. v. Employment Security Com'n, 2 CCH UNEMP. INs. REP. (Cal.) I 2300 (Super. Ct., Los Angeles County 1958); United Steelworkers v. Doyle, I 68 Ohio St. 324,154 N.E.2d 623 (1958). See Brief for Appellee, pp. 20-22, 3 I-38, In Re Sizuler, 255 N.C. 559, 122 S.E.2d 393 (1961).

${ }^{\text {so }}$ See United Steelworkers v. Doyle, supra note 29. But see Brief for Aluminum Company of America as Amicus Curiae, pp. I1-16, In $R \varepsilon$ Shuler, supra note 29.

${ }^{31}$ The Texas ruling holds that the payments under the SUB plan are "wages." However, the Attorney General in permitting supplementation stated that these "wages" are not applicable to the period for which they are payable but are applicable to a prior period in which earned. Tex. Atty. Gen. Op. No. WW-13, 8 CCH UNEMP. INs. REP. I 820 I (1957). Accord, United Steelworkers v. Doyle, I 68 Ohio St. 324, 330-35, 154 N.E.2d 623, 627-30 (1958) (dissenting opinion). Under this approach it is contended that SUB payments are a deferred wage.

"Although severance payments present a problem similar to supplementation, the North Carolina Court in Shuler failed to distinguish In $R e$ Tyson, 253 N.C. 662, 117 S.E.2d $854(1961)$, in which it overruled the Commission and held severance payments to constitute wages, thus making the recipient ineligible for state unemployment benefits. The Tyson case rests on a narrow statute, providing that payments for "discharge" are wages; whereas SUB benefits are payments due to "layoff." More significantly, Tyson appears to be based on a fear of and opposition to a duplication of state benefits by severance payments to such an extent that the unemployed worker would thereby be receiving more than his normal wage. Moreover, unlike SUB payments, a worker has a vested right to a severance payment, which has a definite relationship to his prior service.

Furthermore, contrary to the Tyson holding, strong arguments have been made that severance payments are not disqualifying wages, and that fear of duplication is not sound. The argument is made that severance payments are deferred wages earned by the employee during his employment; or that such payments constitute partial compensation for loss of seniority, pension rights, and compensation for acquiring a new skill, and as such do not eliminate the need for state unemployment benefits. See 57 Colum. L. Rev. 437 (I957); 36 MinN. L. Rev. I13 (I95I). 
In Re Shuler reaches a decision justifiable on the bases of policy and construction of the unemployment compensation statute, and thus offers the first judicial precedent for the validity of supplementation. However, the confusion inherent in the statutory definitions of "wages" and "totally unemployed," the increasing complexity of SUB plans, and the fact that agency rulings lack necessary reliability indicate the need for further legislation supporting the principle of supplementation.

It is important that SUB and severance payments be distinguished, because the more modern SUB plans may include a severance or lump-sum dismissal payment provision, and some states which permit supplementation prohibit the concurrent payment of severance and state benefits. For example, Arkansas permits supplementation, but in Thornbrough v. Gage, 350 S.W.2d 306 (Ark. 1961), the Arkansas court held that lump-sum SUB payments were disqualifying "wages," and thus the recipient ineligible for state unemployment compensation. 